\title{
THE SHADOW OVER GALICIA: H.P. LOVECRAFT'S OBSESSIONS RESURFACE IN THE FILM ADAPTATION OF DAGON (2001) ${ }^{1}$
}

\author{
John D. Sanderson, Universidad de Alicante \\ Email: sanderson@ua.es
}

\begin{abstract}
With the cinematic adaptation of H.P. Lovecraft's tale The Shadow Over Innsmouth (1931) under the title of Dagon (Stuart Gordon, 2001), many ideological issues which have haunted scholarly appreciation of his literary work have been brought out under a new light. The setting of the film in the Galician coast of Spain, from which many immigrants crossed the ocean towards America, provides a further reading to the hardly concealed xenophobia underlying this and many other tales. Hybridity, linguistic plurality, sexual taboo and other controversial features are updated far more explicitly on screen, proving that Lovecraft's extremist perspective is not a thing of the past.

Keywords: North-American Literature, film adaptation, H.P. Lovecraft, Dagon, The Shadow Over Innsmouth, ethnic stereotypes, popular culture, immigration.

Título en español: La sombra sobre Galicia: las obsesiones de H.P. Lovecraft resurgen en la adaptación cinematográfica de Dagon (2001)

Resumen: Al adaptar al cine el relato de H.P. Lovecraft La sombra sobre Innsmouth (1931) con el título de Dagon (2001), Stuart Gordon genera nuevas posibilidades de interpretación del texto original al transferir la acción a España, concretamente al pueblo ficticio de Imboca (obvia derivación del original inglés) en la costa gallega. Una decisión puramente comercial activa diversas cargas semánticas subyacentes tradicionalmente adscritas a la obra del autor y vinculadas a su firme rechazo a la emigración hacia Estados Unidos. Estereotipos nacionales, hibridación, xenofobia y otros aspectos controvertidos vinculados a la localización de la película confirman que el extremismo político de Lovecraft sobrevive al cambio de siglo.

Palabras clave: Literatura norteamericana, adaptación cinematográfica, H.P. Lovecraft, Dagon, La sombra sobre Innsmouth, estereotipos nacionales, cultura popular, emigración.
\end{abstract}

The consideration of H.P. Lovecraft as one of the leading writers of the supernatural in the XXth century is now widely acknowledged. Even though during his lifetime his texts were not released by any major publishing company, after his death literary appreciation towards his work increased steadily and a surge of paperback publications in the late 1960s resulted in a slow but evolving increase of related literary criticism which reached its climax when S.T. Joshi, probably the most authorized academic voice on the author, founded a

Date of reception: 14 June 2011

Date of acceptance: 19 July 2011

Odisea, n ${ }^{\circ} 12$, ISSN 1578-3820, 2011, 245-255 
scholarly journal devoted to the author, Lovecraft Studies, in 1979. Since then, Lovecraft's richly descriptive prose, which derives from his own personal observation during his travels, and his ability to convey, mainly through first person narrative, the feeling of fear and unrest at the discovery of the horror which lay beneath what he considered a decaying American society, have made him achieve a cult status in both popular and academic circles.

The film industry also found a profitable literary source in his texts. Almost a hundred audiovisual productions (full-feature films, television, shorts and even video-games) have been registered as based, to a larger or lesser extent, on Lovecraft's work since the 1960s. The first cinematic adaptation was The Haunted Palace (1963), based on The Case of Charles Dexter Ward (1927) with additional dialogue written by none other than Francis Ford Coppola, and produced and directed by Roger Corman, best-known at the time for his string of film versions of another icon of short stories of the supernatural: Edgar Allan Poe. ${ }^{2}$ Lovecraft's imaginatively twisted plots would eventually prove to be of high cinematic value, and the equivalent of the relationship between Corman and Poe would develop in the teaming up of Stuart Gordon and Brian Yuzna, who have been involved in up to seven films based on Lovercraft's texts. Actually, the first full feature film of both their careers, with Gordon directing and Yuzna producing, was Re-animator (1985), based on the series Herbert West: Re-animator (1922).

The critical endorsement of Lovecraft's tales, however, has found a certain degree of reluctance for their sub-textual layers of meaning, which evidenced an ideology that was confirmed by the author's own essays and published letters, where he denounced what he considered was the destruction of American civilization because of massive immigration. His obsession with the superiority of the Teutonic Aryan race, his aversion towards miscegenation and, generally speaking, a paranoid xenophobia transpired in many of his supernatural texts; most fears inscribed in them result from the intervention of subcreatures coming from beyond the American borders and taking over local communities. These openly expressed views have made many critics uneasy about acknowledging the quality of his work. Joshi (2001: 184) himself admits that Lovercraft "was attracted by the fascist ideology".

The cinematic adaptation of his texts, on the other hand, would not seem to have been affected by these issues, since the body of work has been mainly low budget films with the only purpose of producing some harmless fun. But that does not mean they do not convey any ideology. The purpose of this paper is to discuss how a film based on Lovecraft's work, Dagon (2001), a Gordon-Yuzna production, does bring forward some issues mentioned above under a new light, mainly influenced by the fact that the customary American location of his stories was transferred to Spain. Brian Yuzna had founded Fantastic Factory, a production company, there shortly before Dagon was filmed, which led to its shooting in the Galician coast, also encouraged by the public funding granted by its regional authorities, the Xunta de Galicia. The next step was to adapt the script so that it would take place in Spain, one of the countries which had been a source of immigration to America in the author's lifetime, a fact that would therefore supply a further reading to his already heavily loaded subtext. As we shall

\footnotetext{
2 The Haunted Palace was originally advertised as a cinematic adaptation of Poe's work using the title of one of his poems, simply to bank on the success of Corman's previous films.
} 
see, plenty of derivations can be made from this cinematic updating in the current context of production and reception, including archetypical character portrayal, more openly sexual explicitness, and the acknowledgement that Lovecraft's extremist ideology has not decreased in this contemporary adaptation, but simply evolved under a more subtle façade.

His narrative formula is well-known and extremely effective. A cultivated outsider arrives at a remote location, and the hostile locals will attack him in order to prevent a terrible secret, which has to do with the thin line separating human and beast, from spreading beyond its borders. Lovecraft wrote a short six-page story under the title of Dagon in 1917, but this film actually finds its literary source in another longer tale, The Shadow over Innsmouth (1931), published far later, but still transpiring the same obsessions that loomed over most of his writing career. As Lovett-Graff (1997: 176) points out:

While 'Shadow' may be distinguished from his earlier tales of degeneration by its participation in his pantheon of God-like extraterrestrial monsters entombed within Antarctic glaciers or submerged beneath the South Seas, its focus on questions of racial degeneration kept it solidly within the spectrum of anxieties of his early tales.

Most of Lovecraft's tales begin with an outsider arriving at a remote area and giving us a rich physical description of it while inexplicable events progressively unfold. Dagon takes place during World War I and has the customary unnamed first person narrator writing how he escaped in a raft from a war-ship raided by the Germans and arrived at an unknown land. What he found, an altar which resurfaced from under the sea depicting the existence of monstrous creatures which worship a subhuman deity, has now led him to commit suicide at the end of the story as a threatening slimy figure approaches the door of the room where he is writing his final words. In The Shadow over Innsmouth, the chronologically de-contextualized narrator is touring New England when, in Newburyport, he decides to visit the remote decaying seaport of Innsmouth for sheer curiosity after being told by the bus ticket-seller that it is an unlikely touristic destination. The fact that, even though it is a fictional town, the area is recognizable since it is so close to genuine Massachussets locations also mentioned in the text, lends it an authenticity which increases the terrifying impact of the subsequent revelations. Once he gets to Innsmouth, a grocery clerk unwillingly transferred there by a chain store will tell him about some mysterious attitudes of the locals, but it is finally the village drunkard, Zadok Allen, who will uncover the terrible secret of the town: a Captain Obden Marsh from Innsmouth had struck half a century ago a deal with the local residents so that, in exchange for great riches, they would mate with a race of hybrid fish-frog creatures, the Deep Ones. The latter eventually take over the village, and their interbreeding will result in successive generations of immortal monstrous fishhuman creatures. The narrator discards this story as the product of a drunkard's fantasy, but once he is falsely informed that the evening bus has broken down, and he has to stay overnight, he will experience himself the horror of the situation described by Allen, and will narrowly manage to escape from the hordes of cross-bred who are after him in order to stop him from revealing their secret. The final twist of the tale is his realization that he himself is an offspring of this hybridization, as he prepares to dive into the ocean and live as a fish-human forever. 
This tale is an obvious thinly disguised metaphor of Lovecraft's prevailing obsession. As Langan (2007: 543) claims: "the temptation exist(s) to read 'The Shadow over Innsmouth' as springing out of American anti-immigrant xenophobia". The outsider, as in many other Lovecraft tales, has also been impregnated by the widespread disease that is threatening America. In the film, however, the outsider's point of view is that of Paul Marsh, a young stockbroker on a sailing holiday with his girlfriend, Barbara, in a yacht which belongs to the other couple on the trip with them, Howard and Vickie. In the first scene Paul has a nightmare in which he swims underwater and comes across a carved stone surface covered with symbols (a link to the former Dagon tale) and a beautiful mermaid lying beside it. When he is going to kiss her she opens her mouth, full of ragged, pointed teeth, and closes her jaws on him just as he wakes up. The issue of fish-human hybridity is established from the very beginning, and is continued in Dennis Paoli's script $(2000)^{3}$ with double-entendres ascribed to Barbara, who, for instance, complains about Paul's fixation with the stock exchange reports in his laptop during their holiday with "I'd say you were cold blooded", before dumping it herself into the ocean: "There. Now the stock is underwater", lines which hardly do justice to Lovecraft's prose.

One can find a standardization in the narrative point of view of the Gordon-Yuzna cinematic adaptations of Lovecraft's work comparable to their source texts. Jeffrey Combs, the actor playing the part of Herbert West in their first film together, Re-animator, went on take the main role in their following films, From Beyond (1986), Bride of Re-animator (1990), Necronomicon (1993), etc. For Dagon they managed to find a lookalike, Ezra Godden, who also plays the part of Paul Marsh as a cultivated, dark-haired youngster wearing black-framed glasses, very much in the Herbert West cinematic mode. Other nudges for connoisseurs include the Miskatonic University sweatshirt that he wears throughout the film; we should remember that this is the highly prestigious fictional academic institution, ${ }^{4}$ referred to in many of his tales, of the also fictional city of Arkham, Massachussets, where, for instance, Herbert West got his medicine degree.

Far more relevant to this cinematic updating of The Shadow over Innsmouth is, however, the fact that, while in his doomed bus journey towards the village the narrator of the source text describes how "At last we lost sight of Plum Island and saw the vast expanse of the open Atlantic on our left" (2008: 523), ${ }^{5}$ in the film Paul Marsh finds himself at the other end of that ocean, just off the shore of the Galician coast, in Spain, so from Lovecraft's ideological perspective, the original sentiment of fear would now be increased by the fact that the outsider is actually visiting one of the countries the invading forces came from. This variation encourages, therefore, a further conceptual interpretation, since most Spanish immigrants who left for America came from this region, to the extent that in countries such as Cuba, Argentina or Uruguay, regardless of their origin, all immigrants coming from Spain were collectively called Gallegos in a purposeful demeaning tone. In the first two decades

\footnotetext{
A copy of the script was supplied to me by Asunción Balaguer, widow of the late actor Francisco Rabal, which includes his annotations. The cover includes the information that it was the eighth draft of the script, dated October $5^{\text {th }} 2000$.

4 Jones (2002: 131), among other scholars, relates it to Brown University.

5 All the quotations from Lovecraft's tales have been taken from An H.P. Lovecraft Anthology. More than Fifty

Weird Tales, a publication of Forgotten Books which is also very suitably available on-line.
} 
of the XXth century, it is believed that up to 100.000 Spanish immigrants per year were crossing the Atlantic Ocean, and by 1926, according to Fernández Santiago (2008: 222), there were four Galician immigrant associations in New York alone, which gives an idea of the vast numbers involved. Lovecraft lived in New York between 1924 and 1926, so he had a first person experience concerning this phenomenon, and it had a profound effect in his literary work. In Cool Air (1928), for instance, the unnamed first-person narrator has actually arrived at New York in Spring 1923 and managed to find a lodging slightly above standards, considering the nationality of its inhabitants. He gives us some details:

The landlady, a slatternly, almost bearded Spanish woman named Herrero, did not annoy me with gossip or with criticisms of the late-burning electric light in my third-floor front hall room; and my fellow-lodgers were as quiet and uncommunicative as one might desire, being mostly Spaniards a little above the coarsest and crudest grade. (ibid: 171)

Events will expectedly develop for the worse in this tale, so the fact that the outsiders in the film will also enter Spanish territory with fatal consequences is not at all out of bounds of the generalized features of Lovecraft's work, even though his archetypical unnamed narrator did not venture beyond American soil to confront adversity.

Further surprises lie ahead in the cinematic adaptation. When Barbara suggests going into town for a drink, she rounds it off with a mysterious "Let's visit the mother country!" Paul then feels obliged to reveal to the other couple that his mother "was born around here somewhere - liked it so much she ran away to the States". "And now you're here. Full circle", is Barbara's climatic comment. And one of the first full circles is established between tale and film as well since, as Zadok had revealed to the outsider, Obden Marsh's "mother seems to've been some kind of foreigner". Both mothers had subsequently spread the unnamable disease in American soil, and their hybrid offspring would suffer the consequences of the lack of control concerning immigration. As Kneale (2006: 113-4) foregrounds in his analysis of Lovecraft's ideology: "Hybridity is something that eventually returns to haunt future generations, as it does in 'The shadow over Innsmouth"'.

The Galician town they visit is called Imboca, an obvious derivation of Innsmouth, since "boca" is Spanish for "mouth", and the spelling rules of the language require an $/ \mathrm{m} /$ before the phoneme /b/. The name would also establish a paronymic relationship with "invoca", which is Spanish for "invoke", very appropriate for the supernatural circumstances that will develop in tale and film. And if we compare the urban landscape from the point of view of the outsider, Innsmouth and Imboca are also very close. Once Lovecraft's narrator arrives at Innsmouth, he gives us an adjectivally rich physical description, based on the author's own exploration of economically depressed areas in Massachussets: "Collapsing huddles of gambrel roofs formed a jagged and fantastic skyline, above which rose the ghoulish, decapitated steeple of an ancient church. Some houses along Main Street were tenanted, but most were tightly boarded up. Down unpaved side streets I saw the black, gaping windows of deserted hovels" (2008: 528)

Paoli's script also provides descriptive clues about the landscape Paul and Barbara have found once they reach the town to get help for the other couple, stranded in the yacht after hitting a reef: "Houses and the few storefronts on both sides are blank, dreary, some 
boarded up, apparently deserted.", with the term "boarded" suitably located in both texts to imply secrets which are kept inside. The film location is actually the Galician village of Combarro, in the province of Pontevedra, astoundingly intact after the urban ravishing of the area, a beautiful place which does not seem to have noticed time go by, with its "hórreos", raised granaries built upon pilasters, just off-shore, and its half a dozen "cruceiros", crosses set up at the top of the houses to protect the community's fishermen from the wandering lost souls which supposedly appear on stormy nights. "Lovecraft's passion for finding entire landscapes that would envelop him in the past" (Evans 2005: 113) would have been fulfilled with Combarro, and his proneness to locate fictional communities within realistic geographical areas has also been recreated on film, since Paoli thoroughly places Imboca in the Galician map. When Barbara is abducted by the villagers, the local priest justifies her disappearance to Paul by falsely claiming that she is looking for help "in Santiago, fifty kilometer. No police in Imboca". Combarro is fifty kilometers away from the well known pilgrimage landmark.

That priest is the first Spaniard Paul meets, and he knows what to expect as far as his origin is concerned, which is more than can be said of the source text's narrator first encounter with a native of Innsmouth, Joseph Sargent, the man who runs the bus connection with Newburyport: "Just what foreign blood was in him I could not even guess. His oddities certainly did not look Asiatic, Polynesian, Levantine, or negroid, yet I could see why the people found him alien. I myself would have thought of biological degeneration rather than alienage." (2008: 522) The equivalence established between foreignness and degeneration clearly conveys Lovecraft's views on immigration, and how it has an effect even on the architectural features of the communities invaded: "Somehow these people seemed more disquieting than the dismal buildings, for almost everyone had certain peculiarities of face and motions which I instinctively disliked without being able to define or comprehend them." (ibid: 524) The acknowledgment of the irrationality of this reaction in the narrator could have given a hopeful lead for some further reflection in order to justify it, but the author himself had already made clear in an early essay, In a Major Key (1915), that this "gut reaction" is intrinsic to humanity and something to be proud of rather than ashamed (as quoted in Kneale 2006: 116): "Race prejudice is a gift of Nature, intended to preserve in purity the various divisions of mankind which the ages have evolved". Interestingly, the narrator's reaction towards the inhabitants of Innsmouth is worded very similarly to that expressed towards the Spanish neighbor living in the floor above in Cool Air: "as I saw Dr. Muñoz in that blast of cool air, I felt a repugnance which nothing in his aspect could justify" (2008: 172). Stuart Gordon might have inadvertently brought together the aversion of both narrators by locating Innsmouth on Spanish soil.

But it is not physical appearance the only characteristic which the narrative voice abhors. Another revolting feature is the sound made by the creatures, a perception which brings them closer to their animalistic nature in many of Lovecraft's tales. In Innsmouth, the narrator escapes from the hotel during the night once he hears the hunting party crawl up the staircase after him, and in the street he conceals himself while he hears "the noises swelled to a bestial babel of croaking, baying, and barking without the least suggestion of human speech. Were these indeed the voices of my pursuers?" (ibid: 553). The use of the term "babel" is clearly a giveaway of how Lovecraft felt about a plurality of languages 
spoken within one community, and one can imagine how devastating those two years living in "the melting pot" must have been for him. The term can also be found, for instance, in an earlier tale, The Horror of Red Hook (1925): "The population is a hopeless tangle and enigma; Syrian, Spanish, Italian, and negro elements impinging upon one another, and fragments of Scandinavian and American belts lying not far distant. It is a babel of sound and filth" (ibid: 150). Red Hook, a small peninsula of Brooklyn, would not be celebrated for the diversity of cultures filling the streets with a wide range of languages, but vilified for the threat it posed to those purer white inhabitants living nearby.

In the film version, however, this "croaking, baying, and barking" can be identified as human speech, since it is all verbalized in the Galician language, which gives yet another twist to this adaptation of Lovecraft's work. Gordon explains that, during the pre-production process: "Tuve que enviar los guiones para que los aprobasen, dado que la Xunta participaba en la financiación, y estaba un poco nervioso, porque les pasan cosas un poco extrañas a los turistas. Pero la única corrección que hicieron fue donde me refería al gallego como dialecto, anotando que era una lengua" (La Voz de Galicia October 31st 2001). ${ }^{6}$ Neither term, dialect or language, is mentioned in the final version, an irrelevant issue, in any case, compared to the fact that the only Galician we can hear in the film is uttered by this monstrous hybrid tribe, which gives an example of political shortsightedness on behalf of the Xunta de Galicia, if they were really concerned with the content of the plot, since the actual use of the language is hardly flattering.

Lovecraft's political extremism, however accidentally, is then brought forward again with this choice of language for the hybrids, and, interestingly enough, it would fit in with a current tendency in Spanish far right-wing politics, which also deplore the linguistic plurality within the country, defending the exclusive use of Castilian (that is, Spanish language as it is known worldwide) as opposed to the other co-official languages: Basque, Catalan, Galician and Valencian. ${ }^{7}$ Therefore, the fact that those responsible for the decay of the Spanish equivalent of Innsmouth would speak one of these languages would be perfectly coherent with Lovecraft's ideology. But there are further coincidences. This same Spanish far rightwing also shares similar views about immigration with the author, blaming it for any kind of national misfortune, especially in times of economical crisis, without considering that this cheaply paid labor which started coming to Spain in the early eighties had a strong influence in the resurgence of the country to begin with. There is even a contemptuous generalizing term referred to any immigrant coming from South-America, "sudaca", which was coined with the Spanish prefix sud-, conveying the meaning of "South", and a pejorative final phonemic sequence that could also establish a paronymic relationship with the verb "sudar", to sweat, that would coherently relate to the xenophobic concept of "the unclean". That this could happen in a country which has been a traditional source of immigration for so

"I had to send the scripts so that they would be approved, since the Xunta participated in the funding. I was a bit nervous, because some slightly peculiar things happen to the tourists. But the only correction they made was where I referred to Galician as a dialect, writing down that it was a language."

The first two are specifically targeted from the flanks of the far right-wing media, since they are spoken in the two regions (or comunidades autónomas, following the current lexical norm) which question the Spanish state's sovereignty over their territories. 
long (with even a generalizing term applied to Spanish immigrants: Gallego) is painfully ironic. Not that the right wing sympathizers would realize it.

The American film industry, as global cultural communicators, has established an ethnocentric master narrative based on stereotyping features which proves to be very effective as an economizing story-telling device (Sanderson 2010: 69), since the mere presence of specific visual semes ascribed to a community would save the production process from a further development of character and/or plot. Even though Dagon had Spanish public and private funding, it was definitely made for an international audience, and American director Stuart Gordon could easily define archetypical characteristics that would be automatically decoded by the average transnational spectator cinematically brought up by Hollywood films. And it does work, in some cases with a visually descriptive quality comparable to Lovecraft's source text. For instance, the first archetypical Spanish referent to appear on screen, a glass of red wine, is smashed by the wind as the storm breaks out, and its content trickles down the yacht into the ocean; a parallelism will be established later on with the image of the blood of the two female characters which, in separate scenes, will also trickle into the dark depths stirring up the throbbing unnamable desires from the threatening sinister forces below.

Another archetypical presence is religious imagery. The church and the crosses have already been mentioned, but there is an extra element in the village drunkard's flashback reference to older unpolluted times. It was a tranquil period of poverty until the Spanish equivalent of Obden Marsh, captain Xavier Cambarro (with a wink to the name of the actual village where the film was shot), persuades the villagers to give up Catholicism and embrace the Esoteric Order of Dagon, so that they can start worshipping the deity that will bring them wealth in exchange for their acceptance of the hybrid visitors. Consequently, they will start smashing up sculptures of virgins and saints, which, in the collective national consciousness, would evoke newsreel images of the Spanish Civil war, when the defenders of the Republic, socialists and communists, burnt up churches and toppled over religious symbols because the Spanish Catholic institutional authorities openly supported the coup d'état led by Franco. Therefore, the association of left wing politics with this monstrous hybrid project could also add up to Lovecraft's ideological ascendency.

A minor character from the source text is foregrounded in the film version. According to the unnamed narrator's account: "One of the Marsh daughters was a repellent, reptilianlooking woman who wore an excess of weird jewellery" (2008: 528), but she plays no further part in the tale. In contrast, she not only appears in Dagon's first scene as the mermaid in Paul's nightmare, but later on he comes across her when he sneaks into Cambarro's mansion escaping from his pursuers. She is priestess Uxía, Orfeo Cambarro's daughter (which actually makes her great-granddaughter of captain Xavier Cambarro), and she hides Paul from her father because she has been permanently waiting for him to come back to Spain. She incites him to kiss her, but he rejects her in disgust when he notices that she has gills so that she can breathe and undulating tentacles instead of legs, which reveal her hybrid nature. She has not grown a beard, as Lovecraft might have included if we evoke the archetypical description in Cool Air, but her nationality will be visually established in the film with the archetypical convex comb and a small veil that she will wear over her 
head once she leaves the mansion. This semantic load is more related to Andalusia than to Galicia, but international audiences would probably not tell the difference.

A further twist in the script takes place with the revelation that Paul and Uxía are actually brother and sister, since Cambarro had impregnated Paul's mother before she emigrated to the United States. The horror is increased, then, when incest is added to the unnamable repulsive catalogue of sexual practices which Lovecraft had suggested in his source tale as originating beyond the American borders. Interestingly, the cinematic updating of his tales lends itself to an explicitness that would have been unthinkable in his time. Rather than the incestuous kiss, the most impressive moment in the film is the ritual ceremony conducted by Uxía in which Barbara is offered to Dagon for hybrid mating. It is a ghastly final climatic scene, but it has also been shot in a way to make it sexually titillating, as could be expected from a low-budget horror exploitation film. So this graphically explicit XXIst century recreation could also be throwing a new light onto Lovecraft's prudishness towards this taboo subject, especially when descriptive detail is one of the narrative features for which he is customarily praised. Lovett-Graff (1997: 184) sustains: "The similarities between Lovecraft's descriptions of his monsters and his epistolary representations of immigrants underscore the degree to which personal anxieties about sexuality found their material symbolization". According to this, the author would be venting his frustration by means of associating underlying devious sexual practices with the increasing presence of foreigners on American soil. It is remarkable, then, that a commercial strategy of the Gordon-Yuzna string of cinematic adaptations (Re-animator and its sequels, for instance, also overflow with sexual explicitness), would finally bring out into the open a sub-textual obsession that would have been underlying throughout most of the author's work.

The most important secondary part is, however, that of the village drunkard, Zadok Allen, the only 'pure' human left in town. In the film he goes under the name of Ezequiel, perhaps as a reference to the prophet who announced that Jerusalem and its temple would be destroyed, as it so happened when eventually the Babylonians sacked it, an interesting connection with the fate of Innsmouth/Imboca. However, the only religious text he recites in Spanish (he is not a hybrid, so he does not customarily speak Galician) when he is about to be ritually murdered is psalm 23 , which starts "He leadeth me beside the still waters...", one supposes for the obvious oceanic connotation. The part is played by Francisco Rabal, one of the best Spanish actors of all time, internationally acclaimed for his work with well-known European film auteurs such as Michelangelo Antonioni, Luis Buñuel, Claude Chabrol or Luchino Visconti. Stuart Gordon recalls: "Rabal admiraba a Lovecraft, lo que me sorprendió mucho. El primer día que nos encontramos estuvimos tres horas hablando de este autor" (La Voz de Galicia October 12 $\left.{ }^{\text {th }} 2001\right) .{ }^{8}$ Certainly not in English, because Rabal never managed to master the language even though he acted in American films directed by William Friedkin, Gregory Nava or Nick Hamm; not that he needed to, since he would inevitably be typecast as a Spaniard, something that did not happen with the Italian or French directors mentioned above. In any case, this lack of linguistic knowledge actually contributed to a more faithful adaptation of the source text, since Allen's New England

\footnotetext{
"Rabal admired Lovecraft, which surprised me very much. The first day we met we were talking about this author for three hours".
} 
dialect is suitably transferred to the film by means of Rabal's broken English. For instance, Allen's original conjuring up of older times in the village: "they was in bad shape because the fishin' was peterin' aout an' the mills wa'n't doin' none too well”, finds an equivalence with Ezequiel's account to Paul: "san of fischemon, wi poor. Nou fisch in ousen. Sou-ui prey. Bad god, hi nou anser", which is the way Rabal's lines of dialogue were printed separately so that he could vocalize them accordingly. When Ezequiel mixes with hybrids he does mumble a few words in Galician to pretend he is one of them (to fit in with his character, they mainly have to do with local wines such as Ribeiro and Albariño), and will even sing ranxeiras, traditional regional folklore songs. It was to be his last film (he passed away before the premiere), and there is a legend at the beginning of the final credits which reads: "Esta película está dedicada a Francisco Rabal, gran actor y mejor persona". 9

I would like to finish this paper suitably making a reference to the final sentences in The Shadow Over Innsmouth, when the unnamed narrator acknowledges his origin and announces: "We shall swim out to that brooding reef in the sea and dive down through black abysses to Cyclopean and many-columned Y'ha-nthlei, and in that lair of the Deep Ones we shall dwell amidst wonder and glory for ever" (2008: 559). He seems to accept his doom, due to the propagation of the hereditary disease of hibridity, with resignation, though it could also be interpreted as a progressive loss of perception. In the film, however, Paul Marsh is far more reluctant to accept his predetermined destiny, and he tries to put an end to his life following the example of the main character from a far earlier tale written by Lovecraft: Facts concerning the late Arthur Jermyn and his family (1920). In Arthur Jermyn's case, the horrible truth he eventually finds out is that he descends from a Portuguese woman who was actually an ape goddess. Paul, having discovered his equivalent interbred ascendance in bordering Galicia, decides, as Arthur, to pour kerosene over his head and set himself alight in order to avoid an immortal existence as a hybrid. This would be a signal of Paul's unwillingness to accept his doomed future, but, unlike Arthur Jermyn, he does not succeed because, even though he is already on fire, priestess Uxia manages to push him into the dark oceanic pit in time to put out the flames, and then she herself dives after him so that they can both, incestuously, also "dwell amidst wonder and glory for ever", he with a badly deformed burnt face.

To sum up, the purpose of this paper has been to prove that, however candid the intention of transferring one of Lovecraft's tales to film may have been, the inherent underlying features of the author's body of work have impregnated this cinematic updating and, as well as this, the purely commercial conditions of the production have added further layers of meaning to this contemporary adaptation, since the setting of Lovecraft's fictional location in Galicia, Spain, has actually intensified the xenophobic implications of the source text. Lovett-Graff (1997: 188) considers that "with 'The Shadow over Innsmouth', a chapter closes in the book of Lovecraft's life. It was the last tale of degeneration with a subtext about immigration to come from his pen." However, one can observe that, in the following century, with some help from the contemporary updating, recreation and reception of his literarily remarkable texts, in the same way as his immortal monstrous creatures, his also monstrous ideology may still live on.

"This film is dedicated to Francisco Rabal, great actor and even better person". 


\section{REFERENCES}

Berger, V. \& Komori, M. eds. 2010 Polyglot Cinema. Migration and Transcultural Narration in France, Italy, Portugal and Spain. Vienna \& Berlin: Lit Verlag.

Evans, T. H. 2005. "A Last Defense against the Dark: Folklore, Horror and the Uses of Tradition in the Works of H.P. Lovecraft". Journal of Folklore Research 42, 1: 99-132.

Fernández SAntiago, M.X. 2008. “Asociacionismo gallego en América 1871-1960”. El asociacionismo en la emigración española a América. Ed. J.A. BLANCo RodRíGUEZ . Salamanca: UNED- Zamora. 199-233

JANicker, R. 2007. "New England Narratives: Space and Place in the Fiction of H.P. Lovecraft". Extrapolation 48, 1: 56-72

Jones, D. 2002. Horror. A Thematic History in Fiction and Film. London: Arnold.

Joshi, S. T. 2001. A Dreamer and a Visionary. H.P. Lovecraft and his Time. Liverpool: Liverpool University Press.

---., ed. 2007. Icons of Horror and the Supernatural. An Encyclopedia of our Worst Nightmares Vol. 2. Westport, C.T.: Greenwood Press.

Kneale, J. 2006. "From beyond: H.P. Lovecraft and the place of horror". Cultural Geographies 13, 1: 106-126

La voz DE Galicia 2001. "Estreno en Sitges de Dagon, que Rabal rodó en Combarro". http://www.lavozdegalicia.es/hemeroteca/2001/10/12/783108.shtml 14 Jun. 2011

---. 2001. "Podría pasar el resto de mi vida haciendo cine sobre leyendas gallegas". http://www.lavozdegalicia.es/hemeroteca/2001/10/31/812446.shtml 14 Jun. 2011

LANGAn, J. 2007. "The Small-Town Horror". Icons of Horror and the Supernatural. An Encyclopedia of our Worst Nightmares Vol. 2. Ed. S.T. JosHi. Westport, C.T.: Greenwood Press. 537-563

Lovecraft, H.P. 2008. An H.P. Lovecraft Anthology. More Than 50 Weird Tales. Forgottenbooks.org

LOVETT-GrAFF, B. 1997. "Shadows over Lovecraft: Reactionary Fantasy and Immigrant Eugenics”. Extrapolation 38, 3: 175-192.

Sanderson, J.D. 2010. "The Other You. Translating the Hispanic for the Spanish Screen". Polyglot Cinema. Migration and Transcultural Narration in France, Italy, Portugal and Spain. Eds. V. Berger \& Miya Komori. Vienna \& Berlin: Lit Verlag. 49-71. 